
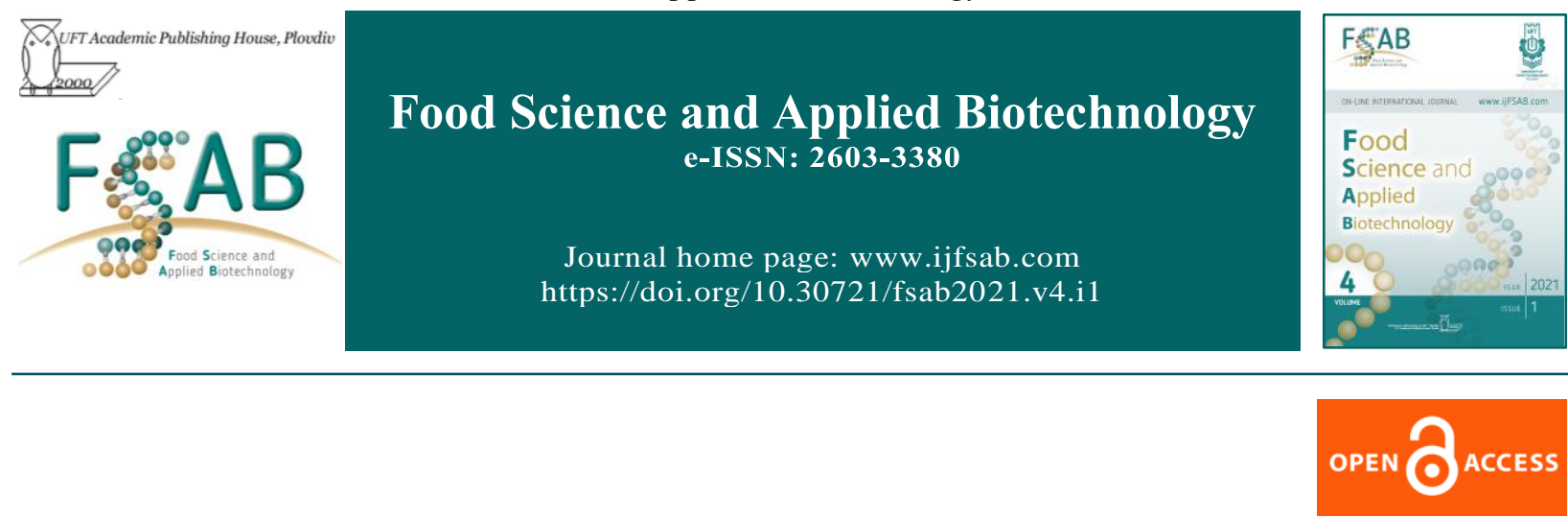

Research Article

\title{
Effect of stage of lactation on somatic cell count in sheep milk of Pleven Blackhead breed
}

\author{
Tatyana Balabanova ${ }^{1 \bowtie}$, Mihaela Ivanova ${ }^{1}$ \\ ${ }^{I}$ Department: Technology of milk and dairy products, Technological Faculty, University of Food \\ Technologies, Plovdiv, Bulgaria
}

\begin{abstract}
Milk secretion in small ruminants present some particularities for cytoplasmatic particles which are shed in the milk together with leukocytes and epithelial cells. Therefore, a parameter like a somatic cell count is worldwide used as a measurement indicator of subclinical mastitis. The aim of the present study was to establish the change of chemical and microbiological characteristics on the composition of sheep milk, obtained from Pleven Blackhead sheep breed during different stages of lactation. It was established that the chemical characteristics of sheep milk varied widely according to the way animals were raised and fed. The obtained results described a slight increase in the values of the total concentration of minerals (up to 1\%) and titratable acidity from 19 to $25^{\circ} \mathrm{T}$. A decrease in the values of total solids (19.2-16.6\%), milk fat (8.0$6.2 \%)$, and protein content (5.8-4.9\%) during the stages of lactation was established. The microbiological analysis showed that somatic cell count and total bacterial count during lactation progressively decreased, probably due to the account the hygienic conditions, nutrition, environment and health status of the animals. Moreover, changes in the composition of sheep milk were directly dependent on stable, stable/pasture and pasture feeding system during lactation period.
\end{abstract}

Keywords: somatic cell count, sheep milk, milk quality, stage of lactation

Abbreviations: SCC - somatic cell count, SNF - solid non-fat, TBC - total bacterial count, TCM - total count of microorganisms, TA - titratable acidity, TS - total solids

${ }^{\square}$ Corresponding author: Chief Assistant Professor Tatyana Balabanova, PhD, Department Technology of Milk and Dairy Products, Technological Faculty, University of Food Technologies, 26 Maritza Blvd., 4002 Plovdiv, Bulgaria, tel.: ++359 32603 770, mobile: ++359898269 539; E-mail: t_balabanova@abv.bg

\section{Article history:}

Received 5 November 2020

Reviewed 2 January 2021

Accepted 21 February 2021

Available on-line 19 March 2021

https://doi.org/10.30721/fsab2021.v4.i1.124

Balabanova and Ivanova1, 2021 (C) 2020 The Authors. UFT Academic publishing house, Plovdiv Effect of stage of lactation on somatic cell count in sheep milk ... 


\section{Introduction}

The agricultural sector is a primary part of the economy of Bulgaria and has a significant impact on overall social and economic development. Sheep breeding is one example of this traditional sector in Bulgarian animal husbandry. The high levels of protein, fat, and calcium by casein unit make it an excellent matrix for cheese production therefore sheep milk is mainly used for the production of high-quality cheese varieties. The composition and properties of sheep milk primarily depend on several physiological factors - breed, variability between individual animals, stage of lactation, seasonal fluctuations, manner of raising and feeding the animals, age, various diseases, etc. (Tamime et al. 2011; Claeys et al. 2014).

The quality of raw sheep milk is determined by its chemical composition and its hygienic environment. Moreover, it is chemical composition of milk that determines this product nutritional value, technological suitability, yield and the subsequent quality of dairy products. The hygienic conditions of milk determine its two main characteristics - total bacterial count (TBC) and total somatic cell counts (SCC). The hygienic conditions of sheep milk are negatively affected by the hygiene standards and the way of milking, the health of the animals, a balanced diet beside the needs, and the physiological condition of the ewes (Idoui et al. 2010; Yilmaz et al. 2011). A high SCC in milk is an indicator of inflammation of the mammary gland (mastitis) (Sharma et al. 2011; Petzer et al. 2017), as SCC reflects the health status of the udder such as immune response of the glandular tissue to the presence of pathogenic microorganisms. There is strong evidence that high SCC values in raw milk result in number of adverse effects that are mainly related to reduction in milk's nutritional value, quality and the cheese yield of dairy products (Halasa et al. 2007; Chen et al. 2010). According to Cinar et al. (2015) and Sharma et al. (2017) the mean values of SCC depend significantly on the origin of the milk and the lactation period. These authors reported that healthy sheep tend to have higher SCC values than those of healthy cows.

The aim of the present study was thus to determine the changes in chemical and microbiological composition of raw sheep milk, obtained from Pleven Blackhead sheep during different stages of lactation.

\section{Materials and Methods}

Raw materials. The study of raw sheep milk was carried out during the period from March to August. A total number of 600 Black-head Pleven dairy sheep were included in the study, fed in different ways (stable, stable/pasture and pasture) and bred in the region of Parvomay, Plovdiv region.

Methods. The samples were examined in the research laboratory of the Department of Milk and Dairy Products, University of Food Technologies, Plovdiv and in the laboratory of the dairy processing plant of Bor Chvor Ltd. The samples were maintained from the time of sampling until the moment of chemical and microbial analysis at temperatures between 2 and $6^{\circ} \mathrm{C}$. No preservative for milk samples was used.

Chemical analysis - The percentages of milk components, including milk fat, milk protein; minerals and lactose, as well as total solids (water content, respectively), solid-non-fat, freezing point and density were determined by Lactoscan SFP Options Milk Analyzer. All analyses were performed at room temperature $\left(24 \pm 1^{\circ} \mathrm{C}\right)$; Titratable acidity (TA) of the milk samples was determined by the Thorner's method according to the Bulgarian National Standard (BNS 1111-80). To $10 \mathrm{~mL}$ of milk sample were added $20 \mathrm{~mL}$ of distilled water, and 1-3 drops of phenolphthalein (prepared at $1 \%$ in $95 \%$ ethanol). The mixture was titrated with standardized $0.1 \mathrm{n} \mathrm{NaOH}$ until the first colour change (to light-pink) persisted for $30 \mathrm{~s}$. One more drop of $0.1 \mathrm{n} \mathrm{NaOH}$ was added and the final volume of $0.1 \mathrm{n} \mathrm{NaOH}$ added was noted. The titratable acidity was represented in degrees Thorner and was calculated by the following formula:

$$
\mathrm{TA}=\mathrm{V} * \mathrm{~F} * 10,{ }^{\circ} \mathrm{T}
$$

where: $\mathrm{V}$ - the quantity of $0.1 \mathrm{n} \mathrm{NaOH}$ used to titrate the milk sample, $\mathrm{ml} ; \mathrm{F}$ - factor of $0.1 \mathrm{n} \mathrm{NaOH}$.

Potentiometric measurement of milk samples active acidity was done by a pH meter (model MS 2000, Microsyst, Plovdiv, Bulgaria) with a glass electrode (Sensorex, Garden Grove, USA) standardized at $20^{\circ} \mathrm{C}$ in the range 7.01-4.01.

Microbiological analysis - SCC was determined by EKOSCOPE -FPS1, produce by Bultech 2000 Ltd, Bulgaria; TBC was determined according to ISO 
4833-1:2013, microbiology of the food chain horizontal method for the enumeration of microorganisms - Part 1: Colony count at $30^{\circ} \mathrm{C}$ by the pour plate technique where the bulk milk samples were decimally diluted in sterilized water to perform serial dilutions of the test sample in order to achieve a colony count of between 15 and 300 colonies per plate. Then the inoculum was transferred into plates and added medium named Plate Count Agar. Inoculated plates were incubated aerobically at $30^{\circ} \mathrm{C}$ for 72 hours. The number of colonies was calculated according to the formula described in the standard. The results were represented as $\log \mathrm{CFU} / \mathrm{mL}$.

Statistical analysis - Computer processing of the results was performed by Microsoft Excel 2010 (ANOVA) with significance level $\mathrm{p} \leq 0.05$ was performed (Draper and Smith 1998).

\section{Results and Discussion}

Table 1 shows the chemical composition of sheep milk obtained during different stages of lactation from Pleven Blackhead dairy sheep. From the data obtained it was evident that during lactation, the values of individual characteristics varied. For example, over the study period it was established that the fat content decreased by approximately $3.3 \%$, and proteins by $1.0 \%$, in contrast to the density, which was relatively law at the beginning of lactation but increased with time and eventually reached $1.037 \mathrm{~g} / \mathrm{ml}$. The observation showed that the freezing point of milk was higher at the beginning of lactation, which may be explained by the higher values of total solids in milk.

Table 1. Chemical composition of sheep milk at different stages of lactation

\begin{tabular}{lcccccc}
\hline Properties & \multicolumn{5}{c}{ Months } & \\
& March & April & May & June & July & August \\
\hline $\begin{array}{l}\text { Water } \\
\text { content, \% }\end{array}$ & $78.96 \pm 0.12$ & $79.79 \pm 0.09$ & $81.24 \pm 0.07$ & $82.39 \pm 0.06$ & $82.96 \pm 0.05$ & $83.19 \pm 0.06$ \\
TS, \% & $21.40 \pm 0.10$ & $20.21 \pm 0.20$ & $18.76 \pm 0.30$ & $17.61 \pm 0.20$ & $17.04 \pm 0.10$ & $16.81 \pm 0.20$ \\
SNF, \% & $11.54 \pm 0.05$ & $11.51 \pm 0.09$ & $11.26 \pm 0.10$ & $10.81 \pm 0.10$ & $10.64 \pm 0.09$ & $10.61 \pm 0.08$ \\
Milk fat, \% & $9.5 \pm 0.1$ & $8.7 \pm 0.2$ & $7.5 \pm 0.3$ & $6.8 \pm 0.2$ & $6.4 \pm 0.2$ & $6.2 \pm 0.2$ \\
$\begin{array}{l}\text { Protein, \% } \\
\text { Lactose, \% }\end{array}$ & $6.0 \pm 0.1$ & $5.9 \pm 0.1$ & $5.7 \pm 0.2$ & $5.3 \pm 0.1$ & $5.0 \pm 0.1$ & $4.9 \pm 0.2$ \\
$\begin{array}{l}\text { Freezing } \\
\text { Point, }{ }^{\circ} \mathrm{C}\end{array}$ & $0.595 \pm 0.005$ & $-0.580 \pm 0.004$ & $-0.555 \pm 0.003$ & $-0.515 \pm 0.002$ & $-0.507 \pm 0.003$ & $-0.503 \pm 0.002$ \\
Minerals, \% & $0.84 \pm 0.02$ & $0.91 \pm 0.02$ & $0.96 \pm 0.03$ & $1.01 \pm 0.02$ & $1.14 \pm 0.03$ & $1.21 \pm 0.04$ \\
$\begin{array}{l}\text { Density, } \\
\text { g/ml }\end{array}$ & $1.032 \pm 0.002$ & $1.032 \pm 0.002$ & $1.034 \pm 0.001$ & $1.035 \pm 0.001$ & $1.036 \pm 0.002$ & $1.037 \pm 0.002$ \\
\hline
\end{tabular}

\footnotetext{
* The results are presented as mean value $\pm \mathrm{SD}$
} 
As lactation progressed, the above mentions values decreased, given the observed tendency for change noted in chemical characteristics of milk. The lactose content did not change during the study period. The obtained results correspond to those established by other authors (Panayotov et al. 2011; Angelov et al. 2015), who studied the dynamics of changes composition of sheep milk. The increased mineral content in sheep milk in the July-August period correlated with the obtained higher values of titratable acidity and the lower $\mathrm{pH}$ values (Figure 1). Xie and Li (2008) noted similar correlations between solids-non-fat values, titratable acidity and buffer capacity in different types of milk.

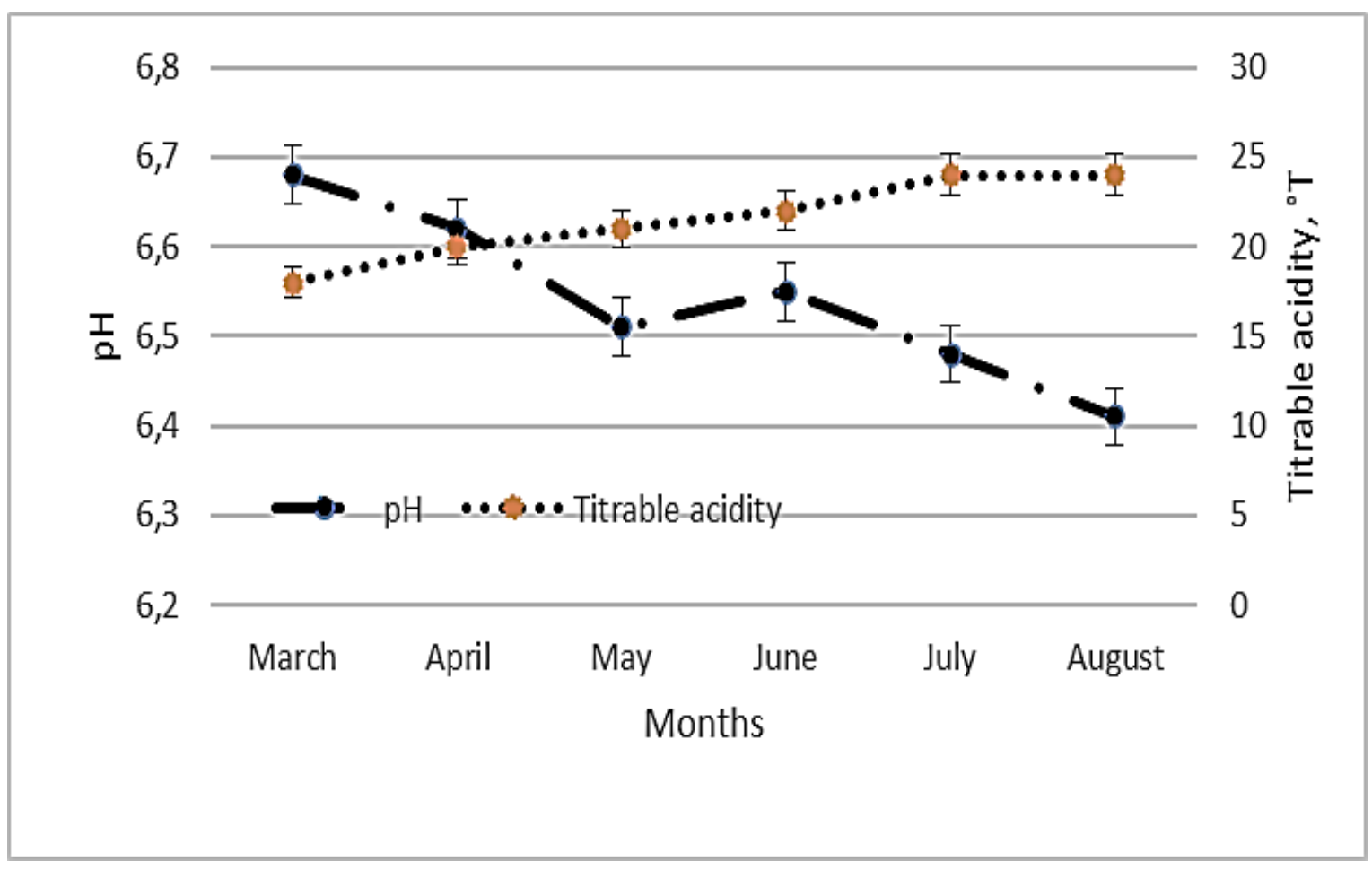

Figure 1. Change of titratable acidity and $\mathrm{pH}$ of sheep milk at different stages of lactation

Similar results were reported from Kandeel et al. (2019) who suggested that a decrease in milk pH was primarily due to an increase in the difference between the concentrations of the main strong cation (sodium) and the main strong anions in milk (chloride and soluble protein) which resulted in an increase in the difference in strong ions. El-Tahawy and El-Far (2010) and Moslehishad et al. (2010) likewise showed a higher percentage of total solids content in milk with an increase in SCC levels.

Figures 2 and 3 present our results for the microbiological characteristics TBC and SCC during the studied period. From the collected results it was evident that the quality of hygiene and animal husbandry improved during the lactation period when comparing the transition from stable to stable/pasture and pasture sheep breeding. A decrease in the total bacterial count and somatic cell count was established during lactation, as a result of free grazing. According to Regulation (EC) No. 853, 2004 of the European Parliament, which treats specific hygiene limits for raw milks TBC values should not exceed $1.0 \times 10^{5} \mathrm{CFU} / \mathrm{mL}$ for raw cow`s milk and $1.5 \times 10^{6} \mathrm{CFU} / \mathrm{mL}$ for raw milk from species other than cows respectively. In raw sheep milk, both microbiological analyses served as indicators of the health status of sheep mammary gland. 


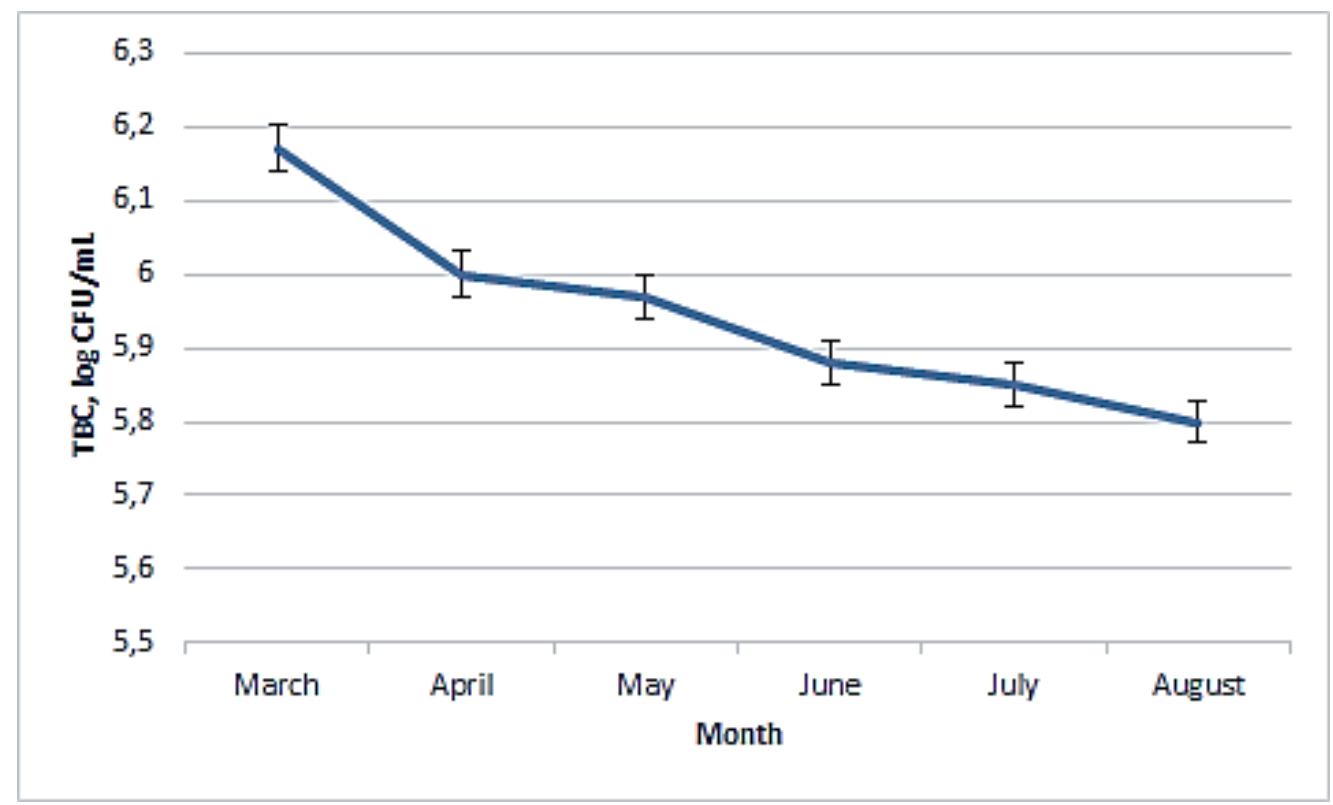

Figure 2. TBC in sheep milk during stages of lactation

Data observed at Figure 2 showed that the TBC values in the March-May period ranged between 6.2 to $6.0 \log \mathrm{CFU} / \mathrm{mL}$, however in June-August period, the TBC decreased and reached values between 5.9 to $5.8 \log \mathrm{CFU} / \mathrm{mL}$. The average TBC value for sheep milk, during the reported period, was $5.95 \mathrm{log}$ $\mathrm{CFU} / \mathrm{mL}$. These results correlated with the results of other authors (Alexopoulos et al. 2011; Merlin Junior et al. 2015) who concluded that the TBC values limit was sometimes exceeded in milk samples. In a study by Muehlherr et al. (2003) the authors reported TBC values of $4.70 \log \mathrm{CFU} / \mathrm{mL}$ (min. $2.00 \log \mathrm{CFU} / \mathrm{mL}$ and $\max .8 .64 \log$ $\mathrm{CFU} / \mathrm{mL}$ ) in small ruminants. According to Klimešová et al. (2017), the development curves of the relationships between TCM and SCC in bulk milk over a period of months may be associated with the dynamics of lactation during the seasonal reproduction cycle of sheep. This result was similar to that noted for small ruminants, in which there was often simultaneous progress within a calendar season, and different from cows reared mostly independently of the seasonal reproduction cycle.
Figure 3 presents the change in the number of SCC in sheep milk during lactation. The obtained data showed that at the beginning of the lactation period, the number of somatic cells was relatively high at 1310000 cells $/ \mathrm{ml}$. As lactation progressed, a gradual decrease in the values was established, and by the end of the lactation period the values decreased by approximately 700000 cells $/ \mathrm{ml}$. A decrease in somatic cell count was also reported by Paape et al. (2007). The data set indicated that milk SCC increased with increasing parity and the stage of lactation for goats and cows but not for sheep. Similar results were reported by Othmane et al. (2002) who noted the non-significant effects of lactation stage and parity on milk SCC. The effect of parity and lactation stage on milk yield, composition and quality of organic sheep milk were studied by Králíčková et al. (2012). They found a significant and positive correlation between the parity and SCC; however, a significant but negative correlation was observed between the stage of lactation and SCC. 


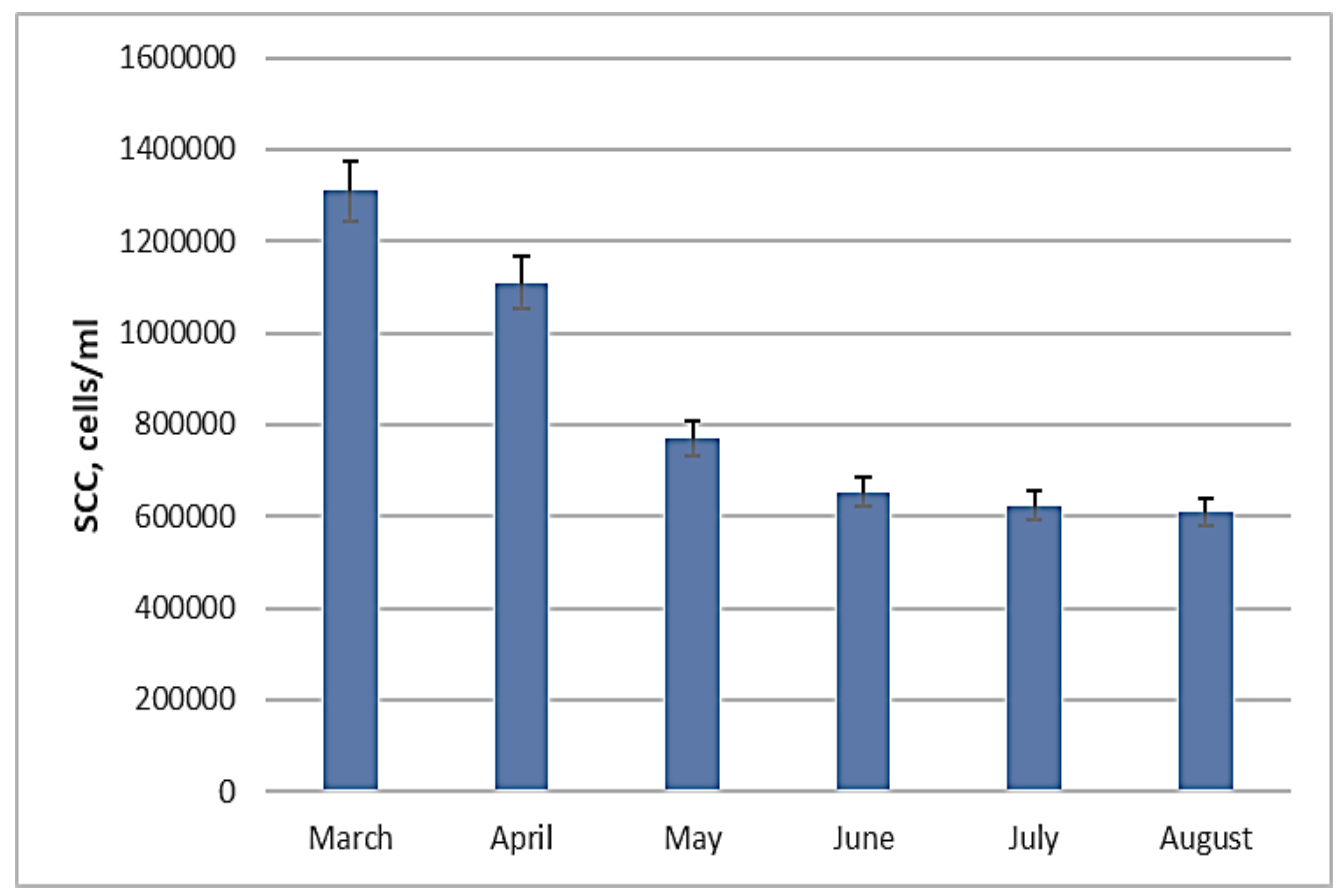

Figure 3. Somatic cell count in sheep milk during stages of lactation

According to Olechnowicz et al. (2010) the SCC in milk samples from udder halves and milk composition depended on the level of SCC recorded for halves of the udder. SCC in milk from one or both halves of udders exceeding $250 \times 10^{3}$ cells $/ \mathrm{ml}$ resulted in a statistically significant $(\mathrm{P}<0.01)$ decrease in the daily milk production of ewes, by approx. 15.89 and $30.22 \%$, respectively. The authors indicated that the analysis of variance also showed a significant effect of parity and lactation stage of ewes on SCC and milk composition from udder halves below $250 \times 10^{3}$ cells $/ \mathrm{ml}$.

\section{Conclusions}

Our study on the chemical and microbiological composition of raw Pleven Blackhead sheep milk showed a clear tendency towards changes over time. A constant tendency towards as decrease in the main chemical characteristics (total solids, SNF, protein and fat content) was observed during lactation. At the same time, there was an increase in the values of minerals, water content, density and titratable acidity. The decrease in the total bacterial count and somatic cell count in milk during different lactation periods was most likely due to the good health of the animals along with the application of good hygienic practices in breeding and feeding. In addition, increase in SCC values causes a decrease in milk yield and affects milk composition, which leads to reduced cheese making aptitude. However, our future research direction is to use this milk to produce a White brine cheese and Kashkaval cheese and to investigate the impact of SCC values on the changes in quality characteristics of these cheese during ripening and storage period.

\section{Acknowledgments}

This study was conducted with the financial support of the Scientific Investigation Section Project 03/20-H, Science Fund, University of Food Technologies, Plovdiv, Bulgaria.

\section{References}

Alexopoulos A, Tzatzimakis G, Bezirtzoglou E, Plessas S, Stavropoulou E, Sinapis E, Abas Z.

Microbiological quality and related factors of sheep milk produced in farms of NE Greece. Anaerobe, 2011, 17(6): 276-9. https://doi.org/10.1016/j.anaerobe.2011.03.011 Angelov L, Ivanova S, Odjakova T. Phisicochemical composition of the white brined cheese from ewe's milk obtained from the middle rhodopean breed 
from the western Rhodopes. Journal of Mountain Agriculture on the Balkans, 2015, 18(4): 619-628. http://www.rimsa.eu/images/stockbreeding_184 2015.pdf

BNS 1111-80:1980. Milk and Milk Products. Determination of acidity. The Bulgarian Institute of Standardization, 1980 [in Bulgarian].

http://www.bdsbg.org/standard/?national_standard_id=15759

Chen S, Wang J, Kessel J, Ren F, Zeng S. Effect of somatic cell count in goat milk on yield, sensory quality and fatty acid profile of semisoft cheese. Journal of Dairy Science, 2010, 93(4): 1345-1354. https://doi.org/10.3168/jds.2009-2366

Cinar M, Serbester U, Ceyhan A, Gorgulu M. Effect of somatic cell count on milk yield and composition of first and second lactation dairy cows. Italian Journal of Animal Science, 2015, 14(1): 105-108. https://doi.org/10.4081/ijas.2015.3646

Claeys W, Verraes C, Cardoen S, De Block J, Huyghebaert A, Raes K, Dewettinck K, Herman L. Consumption of raw or heated milk from different species: an evaluation of the nutritional and potential health benefits. Food Control, 2014, 42(8): 188-201. https://doi.org/10.1016/j.foodcont.2014.01.045

Draper N, Smith H. Applied Regression Analysis. 3rd Edition, John Wiley, New York, 1998, pp: 131-153. https://assets.thalia.media/doc/99/6d/996d25710127-4bd1-9ca1-6900b2ceea81.pdf

El-Tahawy A, El-Far A. Influences of somatic cell count on milk composition and dairy farm profitability. International Journal of Dairy Technology, 2010, 63(3): 463-469. https://doi.org/10.1111/j.1471-0307.2010.00597.x

Halasa T, Huijps K, Østerås O, Hogeveen H. Economic effects of bovine mastitis and mastitis management: A review. Veterinary Quarterly, 2007, 29(1): 18-31. https://doi.org/10.1080/01652176.2007.9695224

Idoui T, Benhamada N, Leghouchi E. Microbial quality, physicochemical characteristics and fatty acid composition of a traditional butter produced from cows' milk in East Algeria. Grasas y Aceites, 2010, 61(3): 232-236. https://doi.org/10.3989/gya.110209

ISO 4833-1:2013 Microbiology of the food chain - Part 1: Colony count at $30^{\circ} \mathrm{C}$ by the pour plate technique. Horizontal method for the enumeration of microorganisms. https://www.iso.org/standard/53728.html

Kandeel SA, Megahed AA, Ebeid M.H., Constable PD. Ability of milk $\mathrm{pH}$ to predict subclinical mastitis and intramammary infection in quarters from lactating dairy cattle. Journal of Dairy Science, 2018, 102(2): 1417-1427.

https://doi.org/10.3168/jds.2018-14993
Kenward M. A method for comparing profiles of repeated manuscripts. Applied Statistics, 1987, 36(3): 296-308. http://dx.doi.org/10.2307/2347788

Klimešová $\mathrm{M}$, Hanuš $\mathrm{O}$, Tomáška $\mathrm{M}$, Hofericová $\mathrm{M}$, Vorlová L, Chládek G, Jedelská R, Nejeschlebová L, Vondrušková E. Correlation between total bacterial and somatic cell counts in bulk tank ewes' milk. Journal of Food and Nutrition Research, 2017, 56(4): 341-350.

Králíčková Š, Pokorná M, Kuchtík J, Filipčík R. Effect of parity and stage of lactation on milk yield, composition and quality of organic sheep milk. Acta Universitatis Agriculturae et Silviculturae Mendelianae Brunensis, 2012, 60(1): 71-78. https://doi.org/10.11118/actaun201260010071

Merlin Junior IA, dos Santos JS, Costa LG, Costa RG, Ludovico A, de Almeida Rego FC, de Santana EAW. Sheep milk: physical-chemical characteristics and microbiological quality. Archivos Latinoamericanos de Nutrición, 2015, 65(3): 193 198.

http://ve.scielo.org/scielo.php?script=sci_arttext\&pi $\mathrm{d}=$ S0004-06222015000300009

Moslehishad M, Hamid E, Mehdi A. Chemical and electrophoretic properties of Holstein cow milk as affected by somatic cell count. International Journal of Dairy Technology, 2010, 63(4): 512-515. https://doi.org/10.1111/j.1471-0307.2010.00616.x Muehlherr JE, Zweifel C, Corti S, Blanco JE, Stephan R. Microbiological quality of raw goat's and ewe's bulk-tank milk in Switzerland. Journal of Dairy Science, 2003, 86(12): 3849-3856. https://doi.org/10.3168/jds.S0022-0302(03)73992-7

Olechnowicz J, Sobek Z, Jaskowski J, Antonsik P, Bukowska D. Connection of somatic cell count and milk yield as well as composition in dairy ewes. Archives Animal Breeding. Archiv Tierzucht, 2010, 53(1): 95-100. https://doi.org/10.5194/aab-53-952010

Othmane MH, De La Fuente LF, Carriedo JA, San Primitivo F. Heritability and genetic correlations of test day milk yield and composition, individual laboratory cheese yield, and somatic cell count for dairy ewes. Journal of Dairy Science, 2002, 85(10): 2692-2698. https://doi.org/10.3168/jds.S00220302(02)74355-5

Paape M, Wiggans G, Bannermana D, Thomasc D, Sanders A, Contreras A, Moroni P, Miller R. Monitoring goat and sheep milk somatic cell counts. Small Ruminant Research, 2007, 68(1-2): 114-125. https://doi.org/10.1016/j.smallrumres.2006.09.014

Panayotov D, Iliev T, Naydenova N, Pamukova D, Simeonov M. Study of milk composition in sheep of Pleven Blackhead breed. Agricultural Science and Technology, 2011, 3(1): 47-49. Available at: http://tru.uni-sz.bg/ascitech/1 2011/3_3.pdf 
Petzer I, Karzis J, Donkin E, Webb E, Etter E. Somatic cell count thresholds in composite and quarter milk samples as indicator of bovine intramammary infection status. Onderstepoort Journal of Veterinary Research, 2017, 84(1): a1269. https://doi.org/10.4102/ojvr.v84i1.1269

Regulation (EC) No 853/2004 of the European Parliament and of the Council of 29 April 2004 laying down specific hygiene rules for food of animal origin.

Sharma N, Singh N, Bhadwal M. Relationship of somatic cell count and mastitis:An overview. AsianAustralasian Journal of Animal Sciences, 2011, 24(3): 429-438.

https://doi.org/10.5713/ajas.2011.10233 Available at: https://www.animbiosci.org/upload/pdf/24-52.pdf

Sharma T, Das P, Ghosh P, Banerjee D, Mukherjee J. Association between udder morphology andin vitroactivity of milk leukocytes in high yielding crossbred cows. Veterinary World, 2017, 10(3): 342347. https://doi.org/10.14202/vetworld.2017.342$\underline{347}$

Tamime A, Wszolek M, Božanić R, Özer B. Popular ovine and caprine fermented milks. Small Ruminant Research, 2011, 101(1-3): 2-16. https://doi.org/10.1016/j.smallrumres.2011.09.021

Xie B, Li Q. Influences of fat content on sensory properties in guangxi buffalo milk. China Dairy Industry, 2008, 2008-02.

Yilmaz O, Çak B, Bolacali M. Effects of lactation stage, age, birth type and body weight on chemical composition of Red Karaman sheep milk. Kafkas Universitesi Veteriner Fakultesi Dergisi, 2011, 17(3): 383-386. https://doi.org/10.9775/kvfd.2010.3585 Available at:http://vetdergikafkas.org/uploads/pdf/pdf_KVFD 930.pdf 